\title{
Egészséges gyermek születése karyomapping eljárással történő preimplantációs genetikai diagnózist követően
}

\author{
Nánássy László dr. - Téglás Gyöngyvér \\ Csenki Marianna dr. - Vereczkey Attila dr. \\ Versys Clinics Human Reprodukciós Intézet, Budapest
}

\begin{abstract}
Az asszisztált reprodukciós beavatkozáshoz kötötten elvégzett preimplantációs genetikai diagnózis mára már egy elterjedt, befogadott módszer szerte a világon. A karyomapping egy teljes genom haplotipizálásán alapuló módszer, ami egypontos nukleotid polimorfizmus array segítségével képes monogénes megbetegedéseket diagnosztizálni. Célunk a karyomapping mint embriódiagnosztikai módszer bevezetése klinikánkon. Primer örökletes glaucomával született gyermek szülei jelentkeztek klinikánkon preimplantációs genetikai diagnózis eljárással kombinált in vitro fertilizációs kezelésre. Hat leszívott petesejtből a három érett petesejt került megtermékenyítésre. A normális termékenyülés jeleit egy zigóta mutatta, amit öt napig tenyésztettünk. Az ötödik napon embrióbiopsziát végeztünk, és a mintát karyomapping eljárással értékeltük. Az embriót heterozigóta hordozóként diagnosztizáltuk. Fagyasztott embriótranszfer eredményeképpen a terhesség 39. hetében egészséges lánygyermek született. A karyomapping eljárást mint preimplantációs genetikai diagnózis módszert Magyarországon klinikánkon elsőként alkalmaztuk sikeresen. A módszer bonyolult preklinikai előkészítés nélkül nagy megbízhatósággal alkalmas monogénes megbetegedést okozó mutációk diagnosztizálására. Orv. Hetil., 2016, 157(51), 2048-2050.
\end{abstract}

Kulcsszavak: preimplantációs genetikai diagnózis, embrióbiopszia, karyomapping

\section{Unaffected child born following preimplantation genetic diagnosis with karyomapping}

Preimplantation genetic diagnosis for single gene defects is a well established method in assisted reproductive technologies. Karyomapping is a genome wide parental haplotyping using a high density single nucleotide polymorphism array that allows the diagnosis of any single gene defects. A couple with an affected child with primary congenital glaucoma attended at our clinic. Six oocyte-cumulus-complex was retrieved and all three mature oocytes were inseminated. One zygote showed the signs of normal fertilization and was cultured for five days. Trophectoderm biopsy and karyomapping analysis were carried out. Result showed a heterozygous carrier for primary congenital glaucoma. Embryo was thawed and transferred and a healthy girl was delivered at term. Here we report the first live birth following in vitro fertilization combined with preimplantation genetic diagnosis using karyomapping in Hungary. Karyomapping is able to accurately detect single gene disorders from a limited amount of samples without a significant preclinical workup.

Keywords: preimplantation genetic diagnosis, embryo biopsy, karyomapping

Nánássy, L., Téglás, Gy., Csenki, M., Vereczkey, A. [Unaffected child born following preimplantation genetic diagnosis with karyomapping]. Orv. Hetil., 2016, 157(51), 2048-2050.

(Beérkezett: 2016. szeptember 19.; elfogadva: 2016. október 24.) 


\section{Rövidítések}

ART $=$ (assisted reproductive technologies $)$ asszisztált reprodukciós technikák; IVF $=$ (in vitro fertilization $)$ in vitro fertilizáció; FET = (frozen embryo replacement) fagyasztott embrió transzfer; $\mathrm{PCG}=$ (primary congenital glaucoma) primer congenitalis glaucoma; $\mathrm{PGD}=$ (preimplantation genetic diagnosis $)$ preimplantációs genetikai diagnózis; $\mathrm{SNP}=($ single nucleotide polymorphism) egypontos nukleotid polimorfizmus; STR = (short tandem repeat) kisméretú tandem ismétlődés

A preimplantációs genetikai diagnózis (PGD) első sikeres alkalmazása óta [1] eltelt több mint két évtizedben számos genetikai betegség diagnosztikája vált lehetôvé embriókban. A molekuláris diagnosztikai módszerek gyors fejlődése lehetővé tette, hogy embrióból nyert mintán, a kiindulási anyag igen csekély mennyisége ellenére is, egyre megbízhatóbb és nagyobb felbontású teszteket végezzünk.

A preimplantációs genetikai diagnózis a praenatalis vizsgálatok legkorábbi formájaként értelmezhetô. Lényeges előnye a módszernek, hogy a genetikai vizsgálat már a terhesség létrejötte előtt elvégezhető, ezzel elkerülve egy esetleges terhességmegszakítást [2]. Ugyanakkor elvégzése csak in vitro fertilizációs (IVF) beavatkozáshoz kötötten kivitelezhető. Célja, hogy a genetikai elváltozást okozó mutációt hordozó embriókat nagy biztonsággal azonosítsa és kizárja azokat a beültetésre kerülők közül.

Az első trimeszterben bekövetkező spontán vetélések legalább feléért a kromoszóma számbeli hibák (aneuploidiák) tehetôk felelőssé [3], ezek a legfőbb okai az IVFkezelések sikertelenségének. Az embrió kromoszómaszámának meghatározása a beültetés előtt nagyban javítja az eredményességet. A cél nemcsak az adott genetikai megbetegedéstől mentes, hanem aneuploidiát sem hordozó embrió visszaültetése.

2015. január óta intézetünkben négy alkalommal végeztünk IVF-hez kapcsolódó PGD-eljárást különböző örökletes megbetegedések vizsgálatára. Jelen kazuisztikánkban a karyomapping mint embriódiagnosztikai módszerrel végzett első sikeres esetünket írjuk le.

\section{Esetismertetés}

Klinikánkon IVF preimplantációs genetikai diagnosztikával kombinált kezelésre jelentkezett roma házaspár 2014-ben. A 19 éves nópáciens és 23 éves partnerének első gyermeke primer congenitalis glaucomával (PCG) született, amely egy autoszomális recesszív öröklésmenetet mutató betegség. A molekuláris genetikai vizsgálatok a 2-es kromoszómán található CYPlBl gén E387K (1159 GA) homozigóta mutációját mutatták ki, amely a hazai roma populáció tipikus génmutációja [4]. A házaspár további két terhességében, a betegségtől való félelem miatt, a terhesség megszakítását kérte. Az előzetes kivizsgálások során a szülők heterozigóta hordozósága bi- zonyítást nyert. A klinikai genetikai tanácsadás során a pár tájékoztatást kapott, hogy 25\%-os eséllyel születhet beteg gyermekük. A preimplantációs genetikai vizsgálatok közül a karyomapping eljárást ajánlottuk a párnak, amit elfogadtak. A beavatkozást megelőzően a hordozó szülőktőol és a megbetegedést mutató gyermektôl vérvétel útján nyertünk referenciát a karyomapping elvégzéséhez.

A kivizsgálások során meddősséggel összefüggő elváltozás nem volt kimutatható, a partner normális spermiogramértékeket mutatott. A nôpáciens GnRH long protokollal végzett petefészek-hiperstimulációban részesült a petesejtleszívást megelőzően. A beavatkozás során hat petesejtet sikerült nyerni, amelyek közül három volt a termékenyítésre alkalmas második meiosis metafázisában. A termékenyítés intracitoplazmatikus spermium injekcióval történt annak érdekében, hogy az embrióbiopszia során elkerüljük a spermiumokkal való esetleges kontaminációt. A termékenyítést követő 18. órában egy petesejt mutatta a normális termékenyülés jegyeit, amelyet ezt követően öt napon keresztül tenyésztettünk. A tenyésztés harmadik napján az embriót új tenyésztôcseppbe helyeztük és a zona pellucidát megnyitottuk az ötödik napi embrióbiopszia elősegítése céljából. A trophectoderma biopsziáját a termékenyítést követő 120. órában végeztük lézer segítségével. Az embriót ezt követően vitrifikáció útján fagyasztottuk a későbbi esetleges felhasználásig. A bioptátumot PCR-csóbe helyeztük kétszeri PBS- és 1\% PVP-oldatban történő átmosást követóen, és $-20^{\circ} \mathrm{C}$-on tároltuk a genetikai diagnosztikai laboratóriumba való szállítás előtt.

A karyomapping eljárás során az embriót heterozigóta hordozóként diagnosztizáltuk. A diagnózis ismeretében, a fagyasztott embrió transzferre (FET) való előkészítését követôen került az embrió felolvasztásra és visszaültetésre. Két héttel a beültetést követően emelkedett $\beta$ hCGszint, ezt követően hetedik heti ultrahangvizsgálat során egy szívhang volt detektálható. Problémamentes gesztációs időszakot követően egy 2970 g-os élő, érett leánygyermek született császármetszés útján, a terhesség 39. hetében.

\section{Megbeszélés}

Az első sikeres preimplantációs genetikai vizsgálatról megjelent beszámoló több mint 25 éves [1], első hazai alkalmazásról pedig 2002-ben készült szakcikk. Papp és $m t s a i[5]$ a Duchenne-típusú izomdystrophia mutációját 50\%-os eséllyel hordozó nő IVF útján létrehozott elóébrényekból eltávolított blastomerák közül leánymagzatot igazolt két preembriót ültettek vissza, majd szövődménymentes terhesség végén egy egészséges leánymagzat született. Az in vitro fertilizációs kezelés preimplantációs genetikai diagnózissal kiegészítve egy mára már megbízható, jól múködő módszer, azonban a technológia legérzékenyebb része $\mathrm{ma}$ is a diagnózis felállítása egyetlen vagy néhány sejtből. A PCR-alapú diagnosztikai 
módszer esetében a leggyakoribb hiba forrása az úgynevezett allélkiesés (ADO-allele dropout), amikor az egyik vagy mindkét allél amplifikációja sikertelen. Az előbbi esetben a heterozigóta allélok homozigótának tűnhetnek. Ugyancsak probléma, hogy az amplifikáció érzékeny a kontaminációra. Jelenleg a gyakorlatban több, a keresett mutáció közelében lévő informatív polimorf markerekkel együtt vizsgálják a keresett locust multiplex PCR-rel [6]. Az egyik ilyen típusú polimorf marker az úgynevezett kisméretű tandem ismétlődések (short tandem repeats - STR). A másik gyakran használt marker az úgynevezett egypontos nukleotid polimorfizmusok (single nucleotide polymorphism - SNP). Használatukkal a téves diagnózis felállításának kockázata 3-4\%-ról $0,3-0,5 \%$-ra csökkenthető [7].

Hátránya a multiplex módszereknek, hogy gyakran családspecifikus próbák szükségesek, tervezésük és beállításuk nagy szakértelmet igényel, valamint preklinikai validációjuk idő- és munkaigényes feladat.

A karyomapping módszer kidolgozása Handyside és mtsai nevéhez füződik [8]. A karyomapping egy egypontos nukleotid polimorfizmuson alapuló arrayplatform. Mintegy 300000 ponton vizsgálja a genomot, amelyek segítségével, valamint a szülők és egy családtag (legtöbbször az érintett gyermek) haplotípusának ismeretében megállapítható egy keresett szekvencia öröklésmenete. Ehhez informatív markereket használ a módszer, amelyek azok az SNP-k, amelyek a szülőknél különböznek. Így indirekt módon kimutatható, hogy adott allél a mutációt hordozó alléllal azonos-e. Preklinikai vizsgálatok bizonyítottak, hogy a módszer megbízhatóan alkalmas detektálni monogénes megbetegedéseket olyan kis mennyiségü mintákból is, mint amilyen egy embrióbiopsziából várható [9]. A következő lépés, a technika klinikai validálása a hagyományos PCR-alapú módszerrel történt, ennek során a PCR-technikával elért diagnosztikai aránynál magasabb, 99,6\%-os diagnosztikai arányról számoltak be [10]. A módszer továbbá alkalmas a monogénes megbetegedéseket okozó variánsok mellett meioticus triszómiák és monoszómiák felismerésére is [11].

A módszer nagy előnye a többi eljárással szemben, hogy néhány kivételtől eltekintve univerzálisan használható minden monogénes megbetegedés esetében. Az adott mutáció preklinikai beállítása szükségtelenné válik, ezzel jelentősen csökkentve a kivitelezésre szükséges időt és munkát. A karyomapping időigénye harmada-negyede a hagyományos PCR-alapú módszernek [10].

Esetbemutatásunk a karyomapping első sikeres hazai alkalmazásáról szól. A módszer nagy előnye, hogy bonyolult, időigényes preklinikai beállítás nem szükséges, univerzálisan használható a legtöbb monogénes megbetegedést okozó mutáció azonosítására. Mindemellett képes a meioticus aneuploidiákról is információt szolgáltatni.
Anyagi támogatás: A szerzők anyagi támogatásban nem részesültek.

Szerzői munkamegosztás: N. L.: A kézirat megírása, az embriológiai munka elvégzése. T. Gy.: A kézirat megírása. Cs. M.: Genetikai tanácsadás. V. A.: A beavatkozások elvégzése, a kézirat megírása. A cikk végleges változatát valamennyi szerző elolvasta és jóváhagyta.

Érdekeltségek: A szerzőknek nincsenek érdekeltségeik.

\section{Irodalom}

[1] Handyside, A. H., Kontogianni, E. H., Hardy, K., et al.: Pregnancies from biopsied human preimplantation embryos sexed by Yspecific DNA amplification. Nature, 1990, 344(6268), 768-770.

[2] Delhanty, J. D., Wells, D.: Preimplantation genetic diagnosis: an alternative to prenatal diagnosis. Expert Rev. Mol. Diag., 2002, 2(5), 395-399.

[3] Jia, C. W., Wang, L., Lan, Ү. L., et al.: Aneuploidy in early miscarriage and its related factors. Chin. Med. J., 2015, 128(20), 2772-2776.

[4] Vogt, G., Kádasi, L'. L., Czeizel, E.: Homozygous E387K $(1159 \mathrm{G}>\mathrm{A})$ mutation of the CYPlBl gene in a Roma boy affected with primary congenital glaucoma. Case report. [A CYP1Bl gén E387K (1159G>A) homozigóta mutációja primer congenitalis glaucomában szenvedő roma gyermekben.] Orv. Hetil., 2014, 155(33), 1325-1328.

[5] Papp, Z., Fancsovits, P., Bán, Z., et al.: First successful application of preimplantation genetic diagnosis in Hungary. [Előébrénydiagnosztikát követően fogant sikeres terhesség első hazai esete.] Orv. Hetil., 2002, 143(52), 2881-2883.

[6] Gutiérrez-Mateo, C., Sánchez-Garcia, J. F., Fischer, J., et al.: Preimplantation genetic diagnosis of single-gene disorders: experience with more than 200 cycles conducted by a reference laboratory in the United States. Fertil. Steril., 2009, 92(5), 1544-1556.

[7] Wilton, L., Thornhill, A., Traeger-Synodinos, J., et al.: The causes of misdiagnosis and adverse outcomes in PGD. Hum. Reprod., 2009, 24(5), 1221-1228.

[8] Handyside, A. H., Harton, G. L., Mariani, B., et al.: Karyomapping: a universial method for genome wide analysis of genetic disease based on mapping crossovers between parental haplotypes. J. Med. Genet., 2010, 47(10), 651-658.

[9] Natesan, S. A., Bladon, A. J., Coskun, S., et al.: Genome-wide karyomapping accurately indentifies the inheritance of singlegene defects in human preimplantation embryos in vitro. Genet. Med., 2014, 16(11), 838-845.

[10] Konstantinidis, M., Prates R., Goodall, N. N., et al.: Live birth following karyomapping of human blastocysts: experience from clinical application of the method. Reprod. Biomed. Online, 2015, 31(3), 394-403.

[11] Natesan, S. A., Handyside, H. H., Thornhill, A. R., et al.: Live birth after PGD with confirmation by a comprehensive approach (karyomapping) for simultaneous detection of monogenic and chromosomal disorders. Reprod. Biomed. Online, 2014, 29(5), 600-605.

(Nánássy László dr., Budapest, Madarász V. u. 47-49., 7. emelet, 1138 e-mail: labdirector@versysclinics.com) 